. W2 $28 \mathrm{H}_{2}$ 



\title{
THE DEVELOPMENT OF THE PARK SYSTEM OF WASHINGTON.
}

\author{
Paper presented before the Seeond Pan American Scientific Congress, \\ Washington, U. S. A., Doeember 27, 1915-January 8, 1916. \\ By COL. WIMLIAM W. HARTS, \\ In charge Office of Public Buildings and Grounds, Washington, D. C.
}

Washington has always held a unique place among the $c$ apitals of the world. Conceived with pride in the minds of our early statesmen, designed with matchless ability by one of the foremost engineers of his period, constructed from time to time inaccordance with its destiny as foreseen by its founders, it holds to-day among Americars cities a proud place for its beauty, its stateliness, and the high develovment of its: institutions.

The well-known lofty aims of the country's first president are now being realized, for the city of Washington has the distinction of being the only large American city not firmly pledged to ugliness. Other cities may develop interesting spots, their civic centers may reflect credit separately upon their designers; but the entire city of Washington displays so much originality and excellence of design that it is held up as a model which other cities of this country may emulate, but none may excel.

The early history of Washington is not only interesting of itself, with its sidelights of sectional jealousy and intrigue, but shows in a broad way the patriotism and foresight of those great men who were responsible for the formative period of this country's development. Many of the present conditions in Washington which seem haphazard have been the result of trying experiences which can be understood only from a knowledge of its early history. For example, Washington is owned practically outright by the United States Government. The Government owns the streets, it owns the parks and public reservations, it owns the sites on which stand the great public buildings of the Nation; and only those lots and tracts which were reserved to the original holders or which the United States has since sold are now in private ownership. In no other American city does this condition exist.

The necessity for such an ownership was first made apparent at Philadelphia in 1783, when an armed mob of mutinous soldiers of the Revolution marched in a body to that city, demanding their long-overdue pay and threatened Congress while that body was in session there. The city authorities were either unable or unwilling to curb this affront, so that it was then determined that the policing, guarding, and control of its own capital should forever be retained in the hands of the Government. We thus find to-day that the Government carefully guarded its rights in its capital and that at the same time the expansion and beautification of the city became matters of pride and satisfaction under its direction. From that day to this no powers have been delegated by Congress unless thoroughly safeguarded, and even the usual right of suffrage is denied the residents of the city in order that its control may never be disputed.

There is not time in this paper to detail even briefly the struggles of the different sections of the country, which constituted at that time merely a fringe of States along the Atlantic Ocean, to secure, each for its own neighborhood, the location of the future capital. The bitterness and distrust with which Massachusetts Bay Colonies and those on the north viewed the eff orts in this direction made by Virginia and the 
other southern colonies was matched only by the bitterness and distrust evinced by these southern States for their northern sisters. It is sufficient to say that the contest resolved itself finally into a struggle between these two sections, one favoring a site near the head of navigation on the Delaware or Susquehanna Rivers, and the other favoring a site near the head of navigation on the Potomac. General Washington, who was then President, favored the latter site, and in 1790 Congress authorized finally the location of the capital on the Potomac River.

In the same year by an act of Congress a board of three commissioners was appointed, consisting of Mr. Daniel Carroll, Dr. David Stuart, and Mr. Thomas Johnston, who were authorized to acquire the land on which the present city is located. This first commission organized the office of public buildings and grounds, which has been continued uninterruptedly down to the present and is one of the oldest Federal offices in the city of Washington.

The exact location of the site on the Potomac was left to the decision of President Washington, who examined the river from the vicinity of Hagerstown downstream to Georgetown, and four months after the bill for the location of the National Capital became a law he entered upon its execution. Two principal sites were selected by Washington for his examination, one near the mouth of the Monocacy, and the other near Georgetown. In January, 1791, his decision that the latter site had been selected was published, and arrangements were made at once for the purchase of the land and the preparation of a design. Mr Andrew Ellicott was employed to make a survey of the land, and Maj. Charles L'Enfant was selected to prepare a plan for the new city. The site was owned by 19 farmers, from whom the land for the future city was purchased by the commissioners, who paid for it but 25 pounds or about $\$ 67$ per acre. An area of about $1 \frac{1}{2}$ miles in length by $3 \frac{1}{2}$ miles in breadth was thus obtained.

The terms of the purchase were unusual. In view of the great benefit to the owners, they agreed to donate to the United States all of the land required for streets and alleys. Parks, reservations, and sites for public buildings were to be paid for at the rate of 25 pounds per acre. They agreed to donate also one-half of all the remaining land for building lots, retaining for themselves only the other one-half of these lots. The lots given to the Government were to be sold whenever such course seemed most advisable, the proceeds of the sales of these lots by the United States were to be applied to defraying the cost of the construction of public buildings, the first two of which were to be the President's House and the Capitol, known in that day as Congress House. The proceeds were to provide later for roads, lights, and other public work.

The sale of lots began at auction in 1793 , but notwithstanding these favorable conditions they did not produce sufficient funds to pay for the construction of the proposed buildings and to meet other expenses in connection with the city. Building was therefore slow and it was not until 1800, or seven years later, that Congress was able to move to Washington and take up its duties there. The city was still in embryo, although started on most promising lines.

The plan of the city was original. From statements left by Maj. L'Enfant it appears that the highest eminence, known at Jenkins's Hill, was selected first as the site for the Capitol, and that another eminence near the mouth of Tyber Creek was selected next as the site for the President's House. The diagonal road connecting these two buildings, since known as Pennsylvania Avenue, was extended eastward to a bridge over the Eastern Branch, now known as the Anacostia River, and was also extended westward into Georgetown by a bridge over Rock Creek. Maj. L'Enfant proposed in his plan a system of north-and-south and east-and-west streets, designating the north-and-south streets by numbers and the east-and-west streets by letters. His diagonal street system, so original and suitable, took shape in a measure from the original roads. Maryland Avenue was laid out as an extension of the Bladensburg Road, furnishing the second main original diagonal thoroughfare. Pennsylvania 
L5 5348

W $28 \mathrm{H}_{3}$

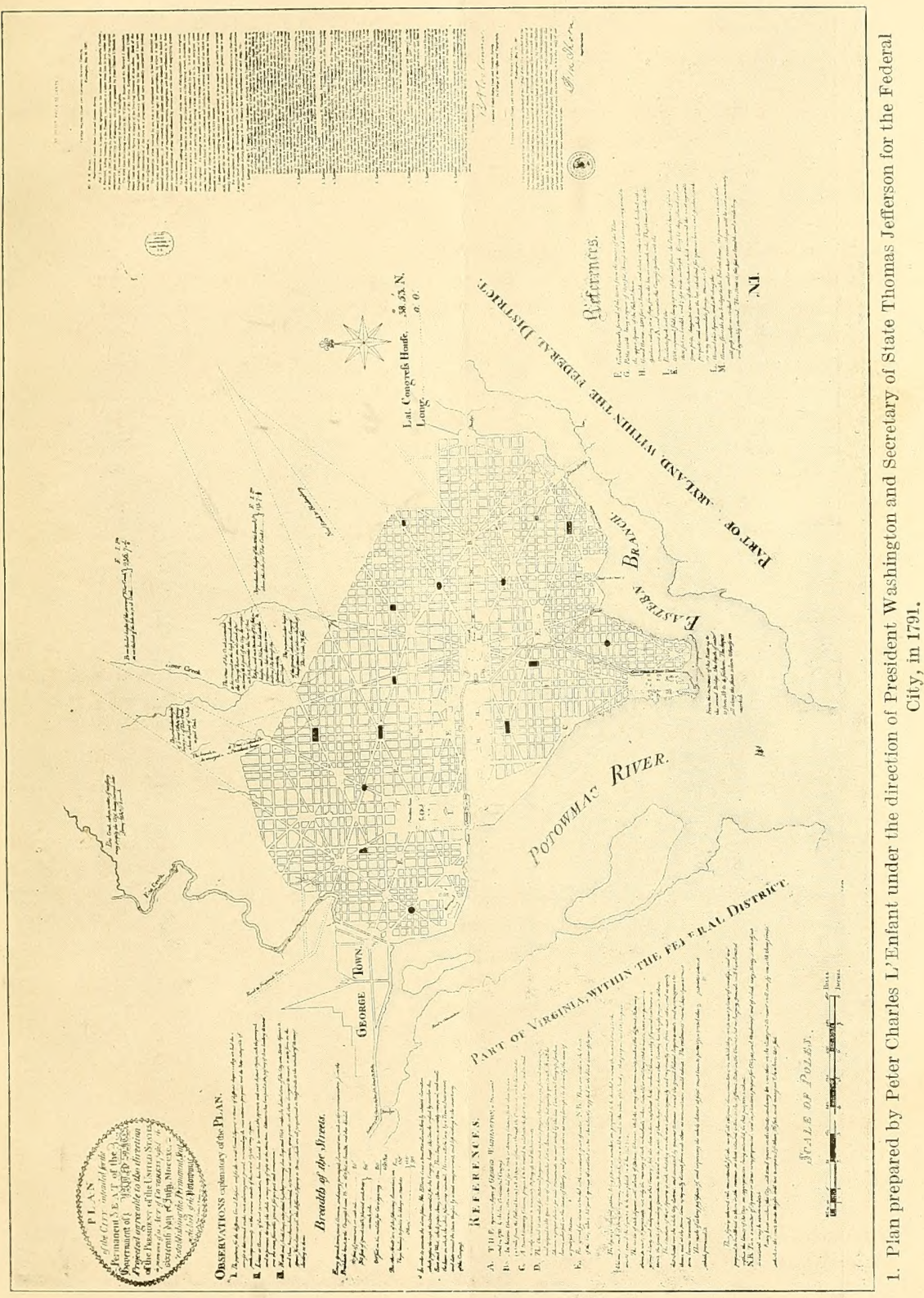

$6-154-1$ 


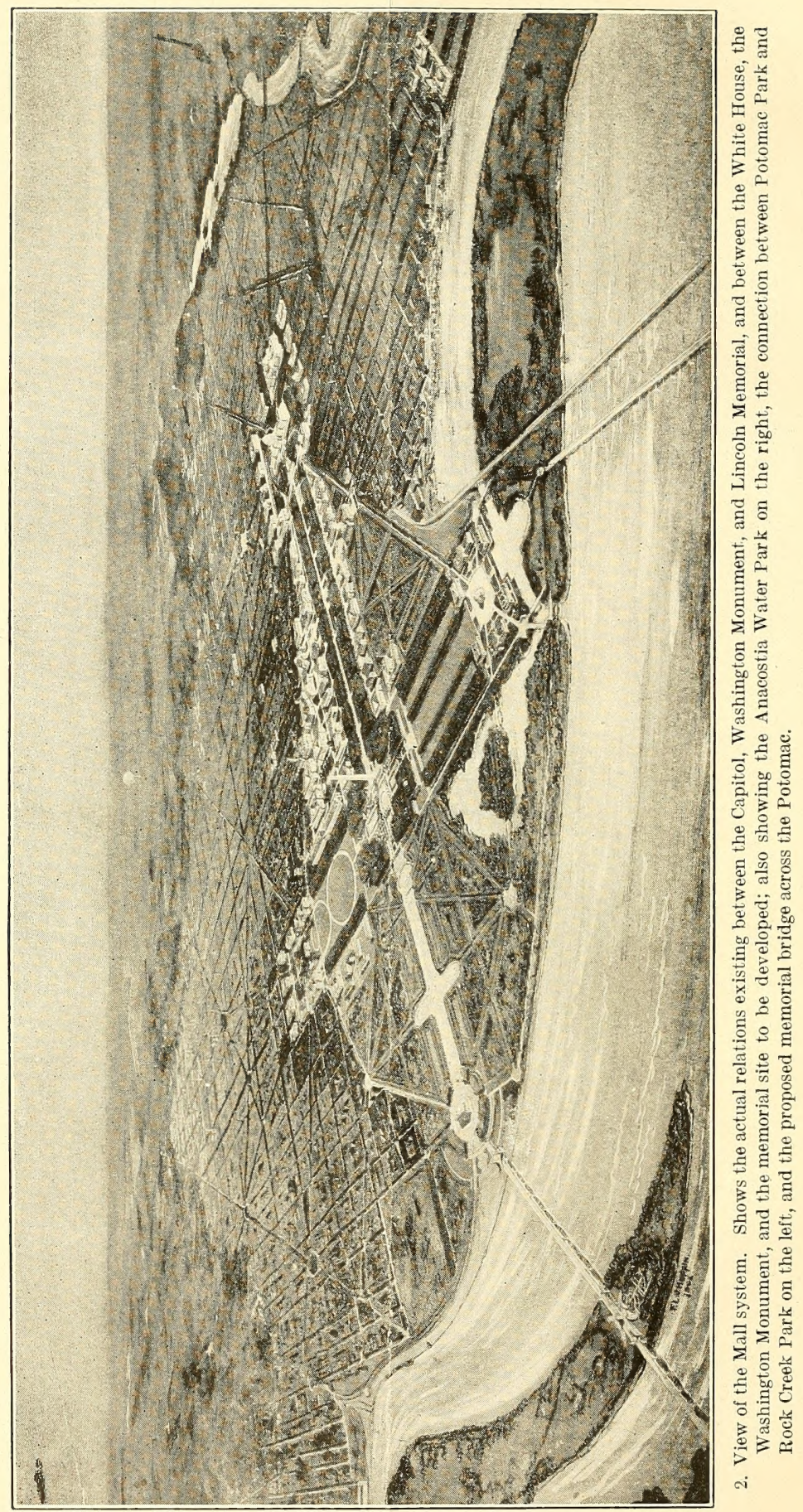




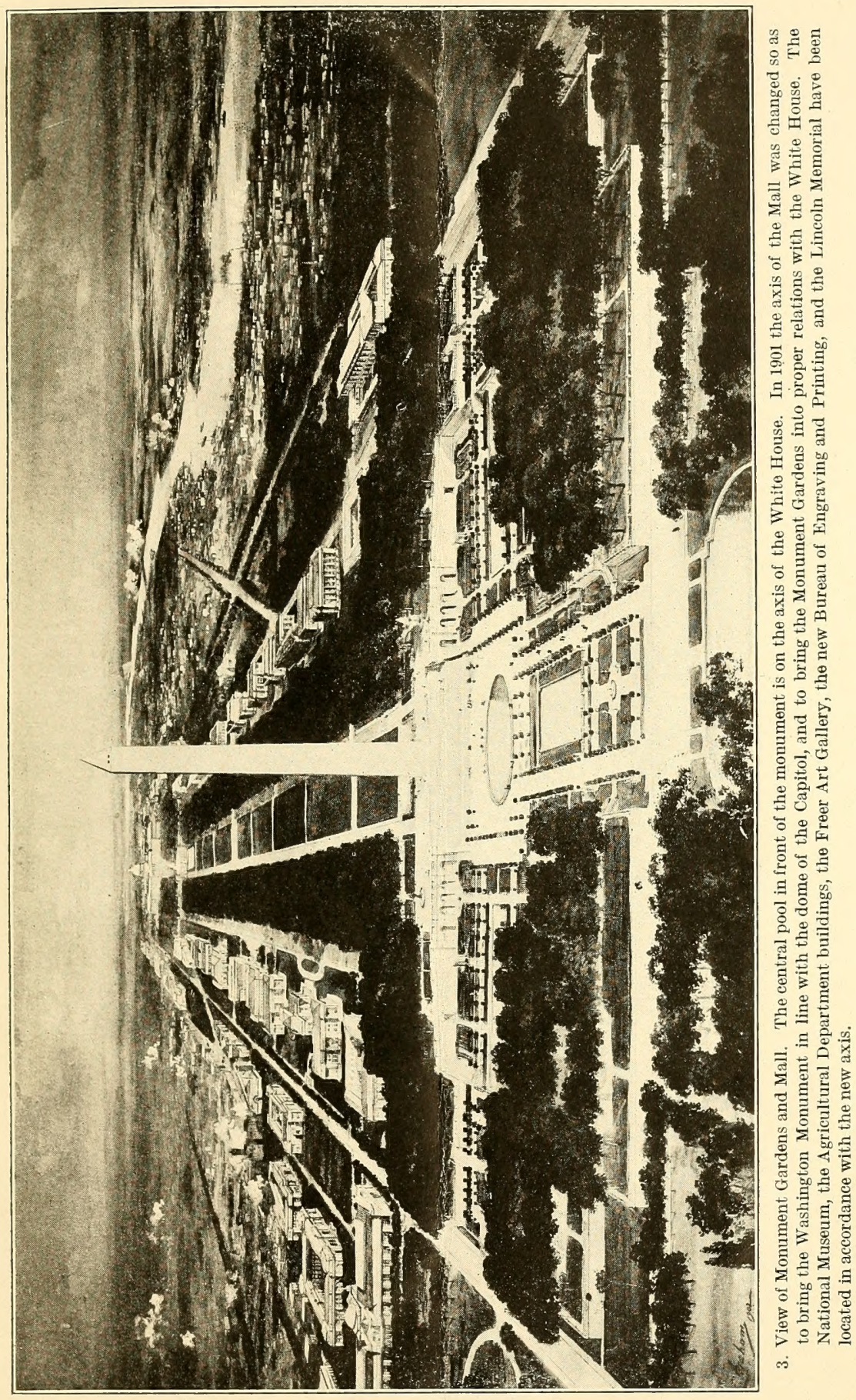




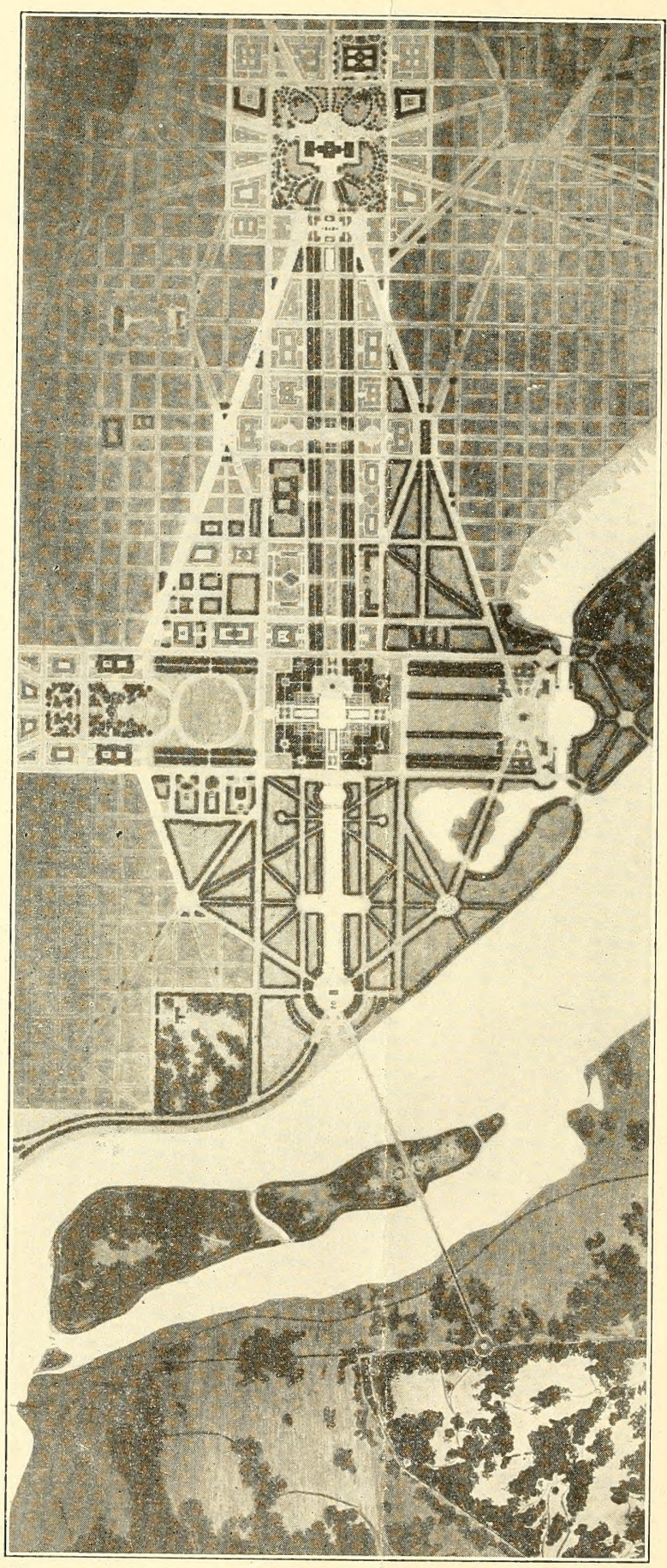

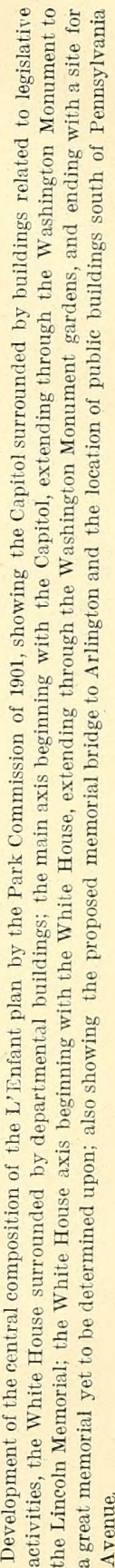

$6-154-4$ 


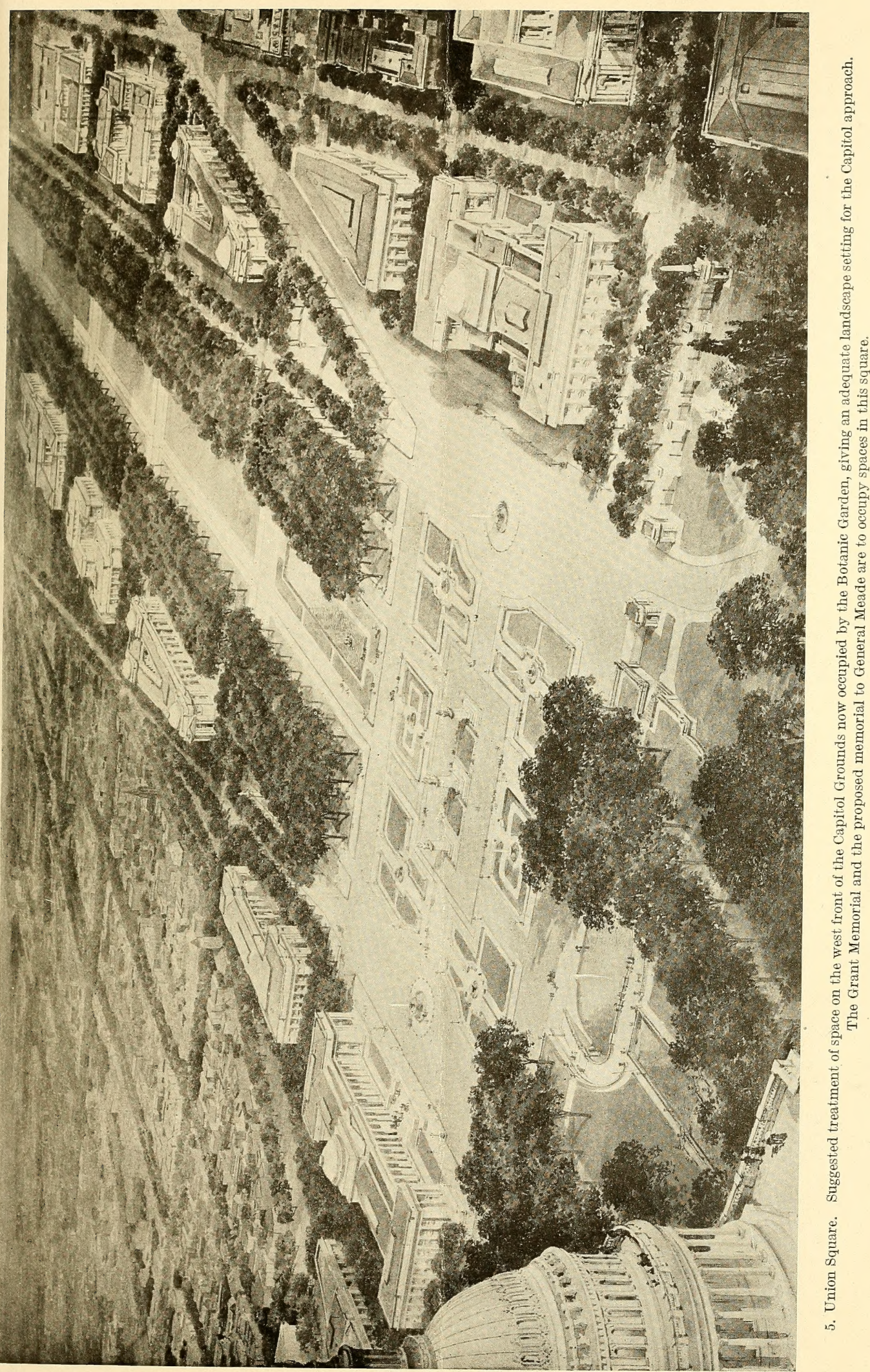




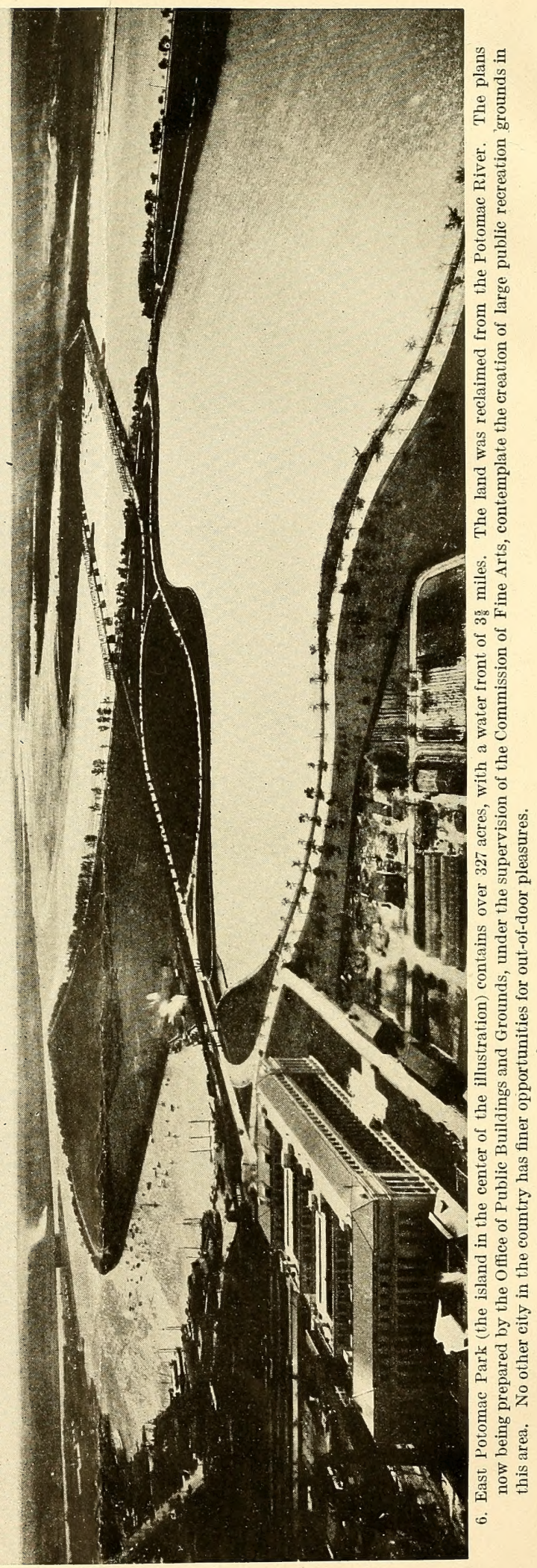




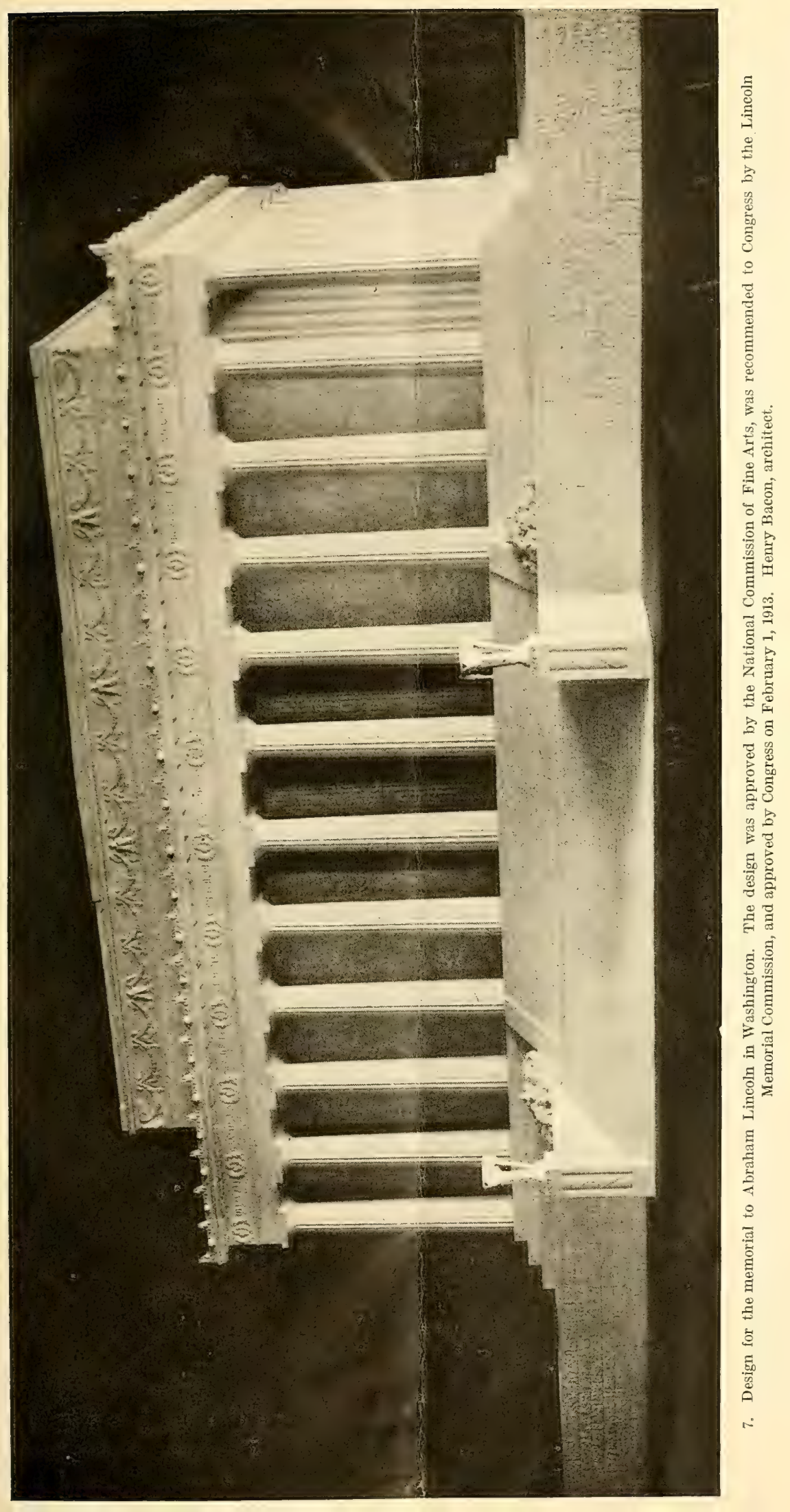



Avenue and Maryland Avenue thus established lines of direction for other parallel and symmetrically placed avenues. The system of centers with radiating streets was thus developed, giving us the many present-day diagonal avenues which make the city so unusual in its artistic development. At the intersections of the streets and avenues there were placed the smaller parks and circles which form a distinguish. ing feature of the city.

L'Enfant desired, in addition, larger areas for more spacious parks elsewhere, and laid out on his plan what was undoubtedly the most pretentious scheme of park development of his day. Of this scheme the Mall plan was the most important feature. It provided a wide parkway extending directly westward from the Capitol, the purpose being to provide for diplomats and other representatives sent to the United States from foreign countries suitable residences facing on both sides a park of unusual beauty. He also selected a site for a national university, and even proposed the con. struction of public institutions of several kinds at places where they would harmonize with his general plan.

The city, as laid out by Maj. L'Enfant, was to provide ultimately for a population of about 800,000 people, the nucleus of which lay between Rock Creek, Florida Avenue, and the Anacostia River, with ample room for expansion northward. The plan proposed by him was a novel one, no city elsewhere in the world having been constructed at that time with diagonal streets radiating from many centers. The plan of Sir Christopher Wrenn, proposed in 1666 for rebuilding a burned section of London by using a circular center and radiating concentric streets, and a somewhat similar plan in the laying out of the city of Annapolis may have both influenced Maj. L'Enfant in his work, for we know that Mr. Jefferson, while Secretary of State, supplied him with many maps of prominent cities, mostly in Europe.

Notwithstanding the excellence of this design, many efforts have been made to disturb the harmony so wisely planned. Robert Morris attempted soon after the city streets were laid out to construct a house projecting into one of the avenues, and the offending portion was torn down by Maj. L'Enfant after an angry controversy of much bitterness.

Many years later the beautiful vistas proposed by L'Enfant, looking toward the White House and the Capitol, were destroyed by the improper location of a number of public buildings, among which the principal ones are the Congressional Library, the Treasury Building, and the State, War, and Navy Building. It is unfortunate that more suitable locations were not selected for these structures, for the mistake appears even more conspicuous to-day than before the development of the city; and it will continue to vex all who appreciate the beauty of the original design. The reason for these mistakes probably lies in the fact that for many years the plans of the city, prepared with so much careful foresight and established with so much difficulty, were regarded with scant recognition of their merit. Even within recent years build. ings of extreme height, such as the Cairo and other apartment houses and structures encroaching upon the park areas, such as the old Pennsylvania Railroad station, were permitted without much restraint.

This condition continued to a greater or less degree until the sudden awakening of the American people to the necessity for securing a higher degree of civic beauty, brought about very largely by the World's Columbian Exposition in Chicago in 1893. At this time the highly artistic design and arrangement of the buildings at this exposition stimulated new ambitions in the minds of all those who were delighted with the wonderful surprise of this exposition.

The first American city to feel the impulse of this awakening was Washington. Senator James McMillan was primarily influential in having called together in 1901 a group of experts, among whom were some of the most eminent architects and artists of the country. Mr. D. H. Burnham, Mr. Charles F. MeKim, Mr. Augustus St. Gaudens, and Mr. Frederick Law Olmsted composed this commission. They visited 
various cities in Europe, and later prepared as a result of their studies the famous plan for the expansion and beautification of Washington, which is now acknowledged generally to be one of the most comprehensive plans for civic beauty in the world. This plan recognizes the great merit of L'Enfant's Mall scheme, but elaborates and expands it to meet the later conditions. It also includes an extension of the park system over the newer part of the city, which was not included in the original design, so that when the natural growth takes place the newer areas will be as well provided with recreation parks as the old.

The central feature of this new plan may be outlined generally as providing for a broad Mall extending from the Capitol westward, including the Washington Monument, to the great memorial to President Lincoln on the bank of the Potomac River. Crossing this line, which forms its major axis, we have a shorter axis extending at right angles north and south through the Washington Monument Grounds with the White House at the northern end, and a proposed group of buildings at the other, dedicated to the memory of the nation's founders. This Mall thus becomes a large diamond, shaped park extending through the heart of the city from the Capitol to the river, providing sites in great number for large public buildings and giving opportunity for an artistic arrangement of trees and roads, and a park development of great dignity and beauty. This Mall scheme will ultimately embrace within its limits nearly all of the great departmental administrative buildings, the Capitol, and the White House, and will provide sites for many semipublic buildings for art and science, for armories and convention halls.

The second essential feature of this commission's plan is a chain of parks connected by boulevards extending from the river through Rock Creek Valley to Rock Creek Park, thence to the Soldiers' Home, through the grounds of the Reform School, thence to the Anacostia River, where a large aquatic park is to be created by filling in the swampy flats, now insanitary and useless, with material dredged from the river channels. Outside of this chain of parks is to be another similar boulevard connecting the Civil War forts, which it is expected will thus become a part of the park system of the District.

Great advance has already been made under the project proposed. Along the Mall new buildings for the offices of the Senate and the offices of the House of Representatives, the new National Museum, the buildings of the Agricultural Department, the recently completed building of the Bureau of Engraving and Printing, the Pan American Building, the Continental Memorial Hall of the D. A. R., and the building for the American Red Cross have all been located with a view to their adding to the ultimate scheme. The Lincoln Memorial is one of the most important of these and marks the western end of the longer axis of the Mall.

Rock Creek Park was acquired in 1892. This is a park of naturalistic design comprising over 1,600 acres. Zoological Park adjoining it on the south, embracing 170 acres, was acquired in 1890. Montrose and Meridian Hill Parks were bought in 1911, and the clearing and opening of the area lying between the Capitol and the Union Station is now in progress.

The water front of Washington, formerly marshes and mud flats, has been filled in with material dredged from the river, and the new proposed area completed and partly developed. The construction of East Potomac Park by reclaiming from the river an area of 327 acres, has just been finished, ready for development as a large athletic recreation field. Plans are now being prepared for the enlargement of Rock Creek Valley with a view to its transiormation into a highly developed parkway connecting Potomac Park on the river front and Rock Creek Park in the interior. On the lower Anacostia River large areas have been reclaimed already by the filling, and work here is still in progress with a magnificent river park in view on that side of the city. 
Never before has the Government undertaken so many extensive plans for the beautification of its Capital. These are being carried out entirely from its own income, no bonds for future payment being issued. The following list shows the areas now in parks:

TABLE A.-Areas of parks and various reservations in the city of Washington and immediate vicinity.

Acres.

Rock Creek Park, under board of control $1,605.9$

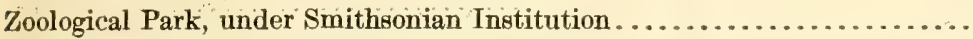

Grounds about the Department of Agriculture, under control of that depart-

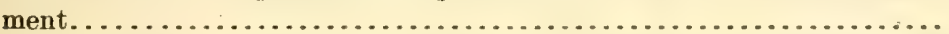

Botanic Garden, under Joint Committee on the Library of Congress........ Capitol Grounds, under superintendent of the Capitol Building and Grounds.

Library of Congress Grounds, under superintendent of Library Building and Grounds

11.3

59.7

118.0

89.8

Naval Observatory grounds, under Navy Department.................

Naval Hospital grounds, under Navy Department...................

16. 9

Soldiers' Home Grounds, under War Department. . . . . . . . . . . . . . . . . .

Washington Barracks reservation, under War Department..............

502.0

62.0

Park system of the District of Columbia, under the jurisdiction and control of the Chief of Engineers, United States Army (approximately 955 acres are included in the Mall section of the city under this jurisdiction $)^{1} \ldots \ldots .1,189.12$

The list above does not include Arlington Cemetery, Fort Myer, the Government Hospital for the Insane, and a number of other public or semipublic reservations to which the public has access, but which were not primarily intended as parks.

Government Hospital for the Insane in Washington, 487 acres.

Arlington National Cemetery, including Fort Myer reservation, 1,363.14 (cemetery proper 408.33 acres, while outlying portions which are occupied and used by the Department of Agriculture amount to 637.67 acres, and Fort Myer at 317.14 acres).

TABLE B.-Detailed statement of areas of parks and reservations under the jurisdiction of the Office of Public Buildings and Grounds.

Grounds south of Executive Mansion -.......

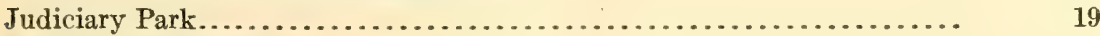

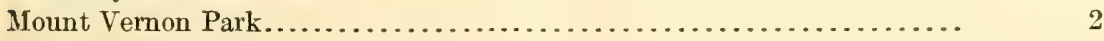

Franklin Park............................................ 4

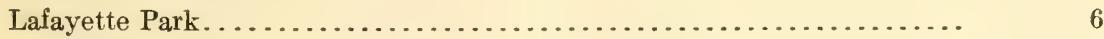

McPherson Park............................................ 1

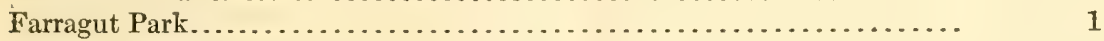

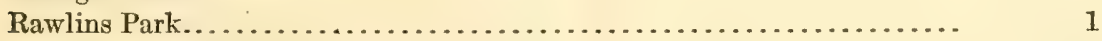

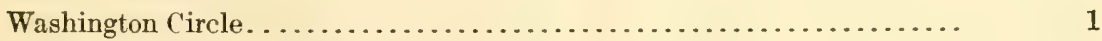

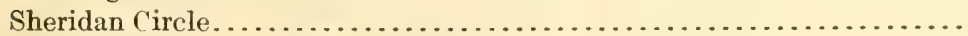

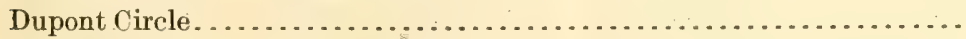

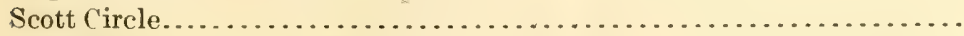

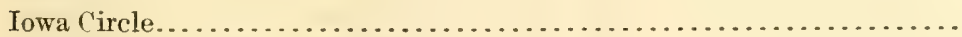

Grant Circle -

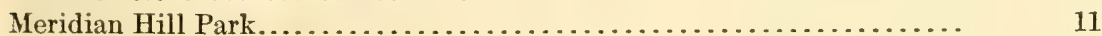

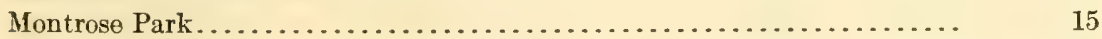

1 This park system is under the administration of the Office of Public Buildings and Grounds. For areas of the several parks, see table below. 
Lincoln Park.

Stanton Park

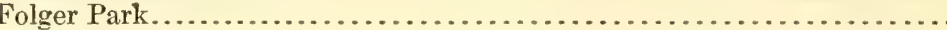

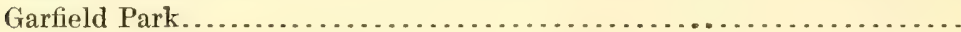

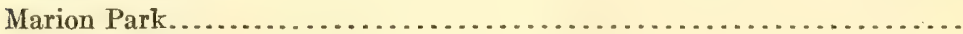

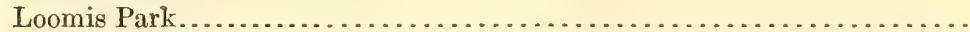

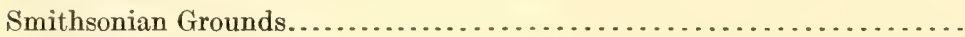

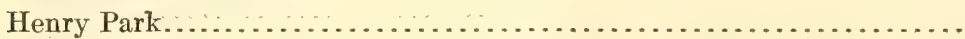

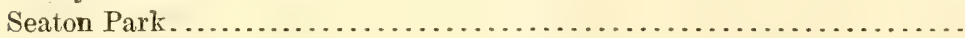

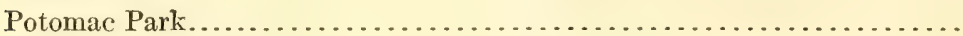

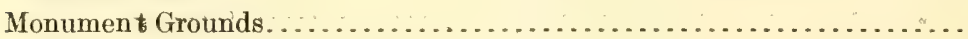

27 named parks (above) containing $\frac{106}{=\frac{1090.07}{10}}$ 27 named parks (above) containing................................... 1, 099. 07 365 small reservations containing........................... 90.05

Total, 392 parks and park places, containing............... 1, 189.12

For many years the supervision of Government areas had been under a commissioner of public buildings and grounds, but in 1867 all reservations which were in the possession of the Federal Government were turned over to the Chief of Engineers of the United States Army for care and supervision. In his hands were placed the appropriations for maintenance and improvement, and an officer in charge of public buildings and grounds, under his direction, was appointed to carry on this work. In 1898 Congress separated more definitely the jurisdiction of the municipal authorities and of the Chief of Engineers, assigning to the former the streets and the parkings along the streets, and to the latter all parks, reservations, triangles, and circles. It was, therefore, not until this latter date, that the park system as such, had a definite existence separate from any control by the city.

The reason for such a separation seems to have been a peculiar one. It occurred within the shadow of our great Civil War. In order to have full control of all circles, parks, and reservations, should these areas be required for military purposes, Congress preferred apparently to retain jurisdiction over them for the United States Government, rather than permit any municipal supervision that might conflict with the Government's needs. It is not surprising, therefore, to find that the separation of the park system from all municipal direction first arose soon after the close of the Civil War, when the remembrance of the military requirements of the United States was still a dominant influence in the administration of public affairs.

Notwithstanding this reason, if there were not a more logical justification for such a separation of jurisdiction, it is probable that the park system of the District would have been returned long ago to the control of the municipal authorities. On the contrary, not a single park has ever been placed by Congress since that time under the exclusive charge of the municipal authorities for park purposes. It is well known that the point of view of the city authorities has been often at variance with the established plans for the beautification of Washington, so that this separation of functions has been found expedient for other reasons and probably will be retained always for the greater protection of the parks and for their closer supervision.

Furthermore, the protection of park property was for many years a duty of the municipal police, but, inasmuch as the main object of the municipal police is the detection and prevention of crime, protection of park property was often considered beneath the dignity of a policeman, and was so neglected that it was found necessary to establish a force of watchmen who would be constantly on the alert to prevent trespass and other encroachment on the public grounds. This force of watchmen was later organized as a distinct body, was clothed by Congress still later with police powers, and is now uniformed and mounted on bicycles at Government expense. Thus we find that necessity forced upon the administration of the parks the organiza- 
tion of the present park police force separate from the Metropolitan force of the city. This necessity not only still exists, and probably always will, but it has been found equally necessary in nearly all the larger cities of the country.

We observe, therefore, that a separate park organization independent of municipal control, and an independent park police force grew out of the necessities of Washington long before their establishment in other American cities. Although many other cities have followed Washington's lead in such matters, this separation is not in effect in Central Park in New York City, this park still being controlled by the municipal government. Those familiar with the struggles of the people of New York since 1854 to avoid encroachment upon the area of this great park for various incongruous pur* poses will readily understand the desirability of separating the park organization from municipal control. Scarcely a half-dozen years passed by in the history of this park that there was not some serious attempt made by the city government to authorize construction within the park area of buildings of a character far removed from park purposes. A hotel was once proposed and authorized, booths for the sale of various articles were at one time suggested, and it was only by public meetings of protest and other vigorous expressions of disapproval, in the newspapers and elsewhere, that many of these encroachments were finally prevented. Even as it is, we find a speedway, the Metropolitan Museum of Art, and some other structures which have restricted the use of this remarkable piece of public property and prevented its utilization for the large public purposes to which it was originally dedicated.

In consequence of these experiences, we find that Chicago, Philadelphia, Boston, St. Louis, and many other large cities, following the example of Washington, have removed their park systems and their park police to a greater or less degree, from municipal supervision. Progress in civic affairs seems, therefore, to indicate that an organization more or less completely separated from municipal control is the wise and expedient course for American cities to follow.

It is not sufficient that such separation alone should be followed. All public areas having the character of parks should be under one management. This seems logical and reasonable, but we find in Washington numerous areas of this character under many different jurisdictions, an unfortunate and uneconomical arrangement. These areas as they were acquired were assigned to various bureaus, in most cases before the definite establishment of the park system of the District of Columbia. Their subsequent inclusion within this park system has never been authorized by Congress, although many recommendations to this effect have been made, notably by Mr. Taft while President of the United States, and by several Chiefs of Engineers of the United States Army. It is expected, however, that these areas will gradually be included within the park system in the future. The lack of economy in administering under different jurisdictions so may similar activities, with the consequent multiplication of overhead charges, should seem apparent to the most casual observer. But customs of this sort are hard to change. It is only the new parks as they are acquired which are placed by law under the legal protection of the park system with its many advantages.

Funds for parks are raised in different ways in various cities, some authorizing a certain amount to be expended annually from the public levies, others authorizing a special tax to be added for park purposes, and still others using special funds secured by law from street railway companies or other public-service corporations. In Washington all appropriations are made by Congress, one-half being paid usually from the income of the Federal Government and one-half from taxes on property in the District of Columbia. An analysis of the appropriations for improvement and maintenance of Washington parks for the past five years is as follows. 
TABLE C.-Statement showing application of appropriations for parks and reservations under the Office of Public Buildings and Grounds for the 5 years from July 1, 1911, to June $30,1916$.

\begin{tabular}{|c|c|c|c|c|c|}
\hline Years. & $\begin{array}{c}\text { Over- } \\
\text { head } \\
\text { (office) } \\
\text { expenses. }\end{array}$ & $\begin{array}{l}\text { Park } \\
\text { protec- } \\
\text { tion } \\
\text { (police). }\end{array}$ & $\begin{array}{c}\text { Park } \\
\text { mainte- } \\
\text { nance. }\end{array}$ & $\begin{array}{c}\text { Park } \\
\text { improve- } \\
\text { ment. }\end{array}$ & Total. \\
\hline $\begin{array}{l}1912 \\
1913 \\
1915 \\
1916 \\
19\end{array}$ & $\begin{array}{r}\$ 19,240 \\
19,240 \\
19,240 \\
19,240 \\
19,240\end{array}$ & $\begin{array}{r}\$ 34,450 \\
33,850 \\
38,650 \\
38,650 \\
39,250\end{array}$ & $\begin{array}{r}\$ 164,670 \\
161,370 \\
164,870 \\
171,370 \\
191,370\end{array}$ & $\begin{array}{r}\$ 40,500 \\
72,500 \\
99,500 \\
117,000 \\
75,500\end{array}$ & $\begin{array}{r}\$ 258,860 \\
286,960 \\
322,260 \\
346,260 \\
325,360\end{array}$ \\
\hline Total for 5 years.. & 96,200 & 184,850 & 853,650 & 405,000 & $1,539,700$ \\
\hline Yearly average ................. & 19,240 & 36,970 & 170,730 & 81,000 & 307,940 \\
\hline
\end{tabular}

The overhead charges cover clerical, engineering, and landscape gardeners' services.

These appropriations are made by Congress on estimates prepared by the officer in charge of public buildings and grounds, submitted to the Chief of Engineers, and by him added to the War Department budget.

The purchase of new areas, if of considerable size, is usually conducted by commissions specially authorized to acquire them by condemnation or otherwise, the limits of area and cost being fixed by the statutes authorizing the acquisition. Rock Creek Park was purchased in this manner. A commission is now preparing for submission to Congress plans of a project for the acquisition of the land along Rock Creek Valley for a new parkway connecting Potomac Park with Rock Creek Park.

Condemnation proceedings are conducted by the Department of Justice, and when the acquisition is completed the area is turned over to the Chief of Engineers for care under the general laws protecting the park system.

The organization under which the parks are cared for and maintained consists of the officer in charge of public buildings and grounds, who is an officer of the Corps of Engineers of the United States Army, under the direct supervision of the Chief of Engineers. Under the officer in charge are the following heads of park departments: (1) Superintendent of parks; (2) head gardener; and (3) superintendent of park police.

Under the superintendent of parks there are, first, a division of design with a landscape architect and several drafting assistants; and, second, a division of maintenance, covering four sections of the city, with a foreman at the head of each section. Under each section foreman there are several parties of workmen attending various parks, making beds, planting flowers, shrubs and trees, sweeping walks, taking up litter, cultivating flowers and bushes, trimming trees, cutting lawns, raking leaves, etc. Responsibility for neglect in any quarter is easily traceable and the neglect promptly corrected. $\Lambda$ careful system of cost keeping by months enables a comparison to be made between the several sections, and affords a sure means of detecting inefficiency or extravagance.

The head gardener, who is the superintendent of the propagating gardens, supervises all planting in the public grounds, the construction of planting beds, and the propagation of flower and foliage plants for the parks. He has about 40 assistants and propagates annually about three-quarters of a million plants for the embellishment of the park flower beds. He also assists in the inspection of new material as it arrives, and has general supervision of the rotation of flower planting and the selection of plants for this purpose. There are 17 greenhouses under his direction, from some of which cut flowers are furnished for the White House.

In the city parks under other jurisdictions various methods of administration are in use. In Rock Creek Park, embracing 1,605.9 acres, which is the largest park in the city of Washington, the authority of supervision and control is vested in a commission consisting of two branches, the Chief of Engineers, on the one hand, and the District 
Commissioners on the other, with equal authority. The executive officer of the Commission is the Engineer Commissioner of the District.

The Zoological Park, containing 167 acres, is under the control of the Smithsonian Institution. The Botanic Garden, at the head of the Mall, is under the control of the Joint Committee on the Library of Congress. The grounds in which the buildings of the Department of Agriculture stand, which form an integral part of the Mall system, are under the control of the Department of Agriculture. The grounds around the Capitol, about 58 acres in extent, are laid out and used as a park and are under the control of the Superintendent of the Capitol. McMillan Park, containing 118 acres, the site of the filtration plant for the water system of the city of Washington, is under the control of the United States Engineer Officer in charge of the Washington Aqueduct. The grounds about the Naval Observatory, amounting to 79 acres, and those around the Naval Hospital, containing 17 acres, are both under the Navy Department. The Soldiers' Home Grounds, covering an area of 502 acres, and the grounds about the Washington Barracks and the War College, containing about 70 acres, are under the War Department. In brief, we may assume that the park area of the District of Columbia comprises in all some 3,700 acres, under 12 different controlling authorities.

Large sums of money are expended annually in beautifying these public grounds, all of which are similar in character, and in which the planting and caring for lawns, flowers, shrubs, etc., require the same kind of supervision and labor. The lack of economy in having so many different organizations is obvious.

Even more objectionable is the lack of harmony in many of the structures heretofore erected under the various jurisdictions, which, if continued, would result in a heterogeneous improvement lacking coordination and unity. This condition is fortunately obviated to a great degree by the functions of the National Commission of Fine Arts. All proposed improvements affecting in any important way the appearance of the city must be submitted to this commission for its comment and advice. The commission is composed of the most eminent experts in their respective professions that the country affords. It consists of three architects, a sculptor, a painter, a landscape architect, and a lay member experienced in civics. These men serve without compensation other than the patriotic satisfaction of seeing that the development of the Nation's capital in its parks, statues, fountains, and public buildings is directed along artistic lines. This body has justified many times its organization and the wisdom of those who were responsible for its creation. Crude and inartistic designs have been wisely excluded and the conformity of public improvements to the Park Commission plans has been aided immeasurably by their patient and profitable advice. The commission is intended to be permanent, under regulations prescribed by the President, who appoints its members. Under an arrangement which has the approval of the President, one or two vacancies occur each year, which are filled with new men, in order that the policy of the commission may be continuous and not subject to sudden change. In this way new ideas may be introduced under the most favorable circumstances, and a broad-minded and progressive course of action assured.

In conclusion, it may be said that in spite of the differences of jurisdiction and of occasional deviations from the approved plans, there is no city in the world in which park development is advancing on more consistent and systematic lines than in Washington; none for which plans are more magnificent and promising; and none in which these plans are adhered to with greater success than in the capital of the United States. 

LIBRARY OF CONGRESS

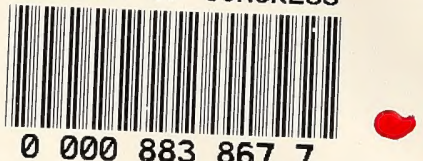

00008838677 